\title{
Double Effects of Interfacial Ag Nanoparticles in a ZnO Multipod@Ag@Bi2S3 Z-Scheme Photocatalytic Redox System: Concurrent Tuning and Improving Charge-Transfer Efficiency
}

\author{
Subrata Mandal and Rajakumar Ananthakrishnan*
}

Department of Chemistry, Environmental Materials \& Analytical Chemistry Laboratory, Indian Institute of Technology, Kharagpur 721302, India

\section{Table of Contents}

1. Schematic of the synthetic procedure for designing various $\mathrm{ZnO}$ structures $\quad \mathrm{S} 2$

2. FESEM images of prepared $\mathrm{ZnO}$ at various condition and PXRD patterns $\quad \mathrm{S} 2$

3. BET isotherms and table of physiochemical properties of various $\mathrm{ZnO}$ structures $\quad \mathrm{S} 3$

4. FTIR spectra of the samples after and before adsorption of $\left[\mathrm{Bi}\left(\mathrm{NH}_{2} \mathrm{CSNH}_{2}\right)_{n}\right]^{3+} \quad$ S4

5. PXRD pattern of synthesized $\mathrm{Bi}_{2} \mathrm{~S}_{3}$ and comparison with simulated XRD pattern $\quad \mathrm{S} 4$

6. FESEM, TEM, and STEM images with mapping of $\mathrm{ZnO} @ \mathrm{Ag}$ binary structure S5

7. FESEM, TEM, and STEM images with mapping of $\mathrm{ZnO} @ \mathrm{Bi}_{2} \mathrm{~S}_{3}$ binary structure S5

8. EDX spectra and table of atomic\% in the hybrids of $\mathrm{ZnO}$ multipod $\quad \mathrm{S} 6$

9. FESEM, HRTEM and SAED pattern of pristine $\mathrm{Bi}_{2} \mathrm{~S}_{3} \quad \mathrm{~S} 6$

10. XPS survey spectra of $\mathrm{ZnO}, \mathrm{Bi}_{2} \mathrm{~S}_{3}$, and their hybrids with table of elements (atomic \%) $\mathrm{S} 7$

11. High resolution XPS spectra of each element present in the hybrid and comparison $\quad$ S8

12. Gas chromatogram analyzed in TCD detector of the gaseous products S8-S9

13. Actinometry and calculation of light intensity and AQY for HER S10-S11

14. Time dependent absorption spectra of MO degradation and their first order kinetics $\quad$ S12

15. Photocatalytic cycle of $\mathrm{ZnO}$ multipod and ternary hybrid for the degradation of MO $\quad \mathrm{S} 12$

16. XRD and XPS survey spectra of the ternary hybrid and table of atomic\% after use $\quad$ S13

17. Photocatalytic $\mathrm{H}_{2}$ production and $\mathrm{MO}$ oxidation rate in presence of scavengers $\quad \mathrm{S} 14$

18. BET isotherms and Table of physiochemical properties of the hybrids S14-S15

19. EIS measurement and table of parameters obtained for the hybrids structure $\quad$ S15

20. UV-Visible absorption spectra of aqueous Nitro blue tetrazolium chloride (NBT) $\quad$ S16

21. Photograph showing photocatalytic production of $\mathrm{O}_{2}{ }^{-}$by $\mathrm{ZnO} \quad \mathrm{S} 16$

22. Absorption spectra of remaining NBT $v s$ time during photocatalytic production of $\mathrm{O}_{2}{ }^{-{ }^{-}} \mathrm{S} 16$

23. PL spectra of the terephthalic acid probe after irradiation of light $\quad \mathrm{S} 17$

24. $\mathrm{C}_{t} / \mathrm{C}_{0} v s$ time plot for the degradation of $\mathrm{MO}$ and a comparison of production of $\mathrm{O}_{2}{ }^{-{ }^{-}} \quad \mathrm{S} 17$

$\begin{array}{ll}25 . \text { References } & \text { S18 }\end{array}$ 
Scheme S1. Schematic illustration of the synthetic procedure for designing various $\mathrm{ZnO}$ structure and optimization of synthetic parameters varying $\mathrm{pH}$ and amount of structure directing agent, right showing illustration of atomic arrangement and surface atomic configurations respective of their various facets from the simulated structure of wurtzite $\mathrm{ZnO}$.
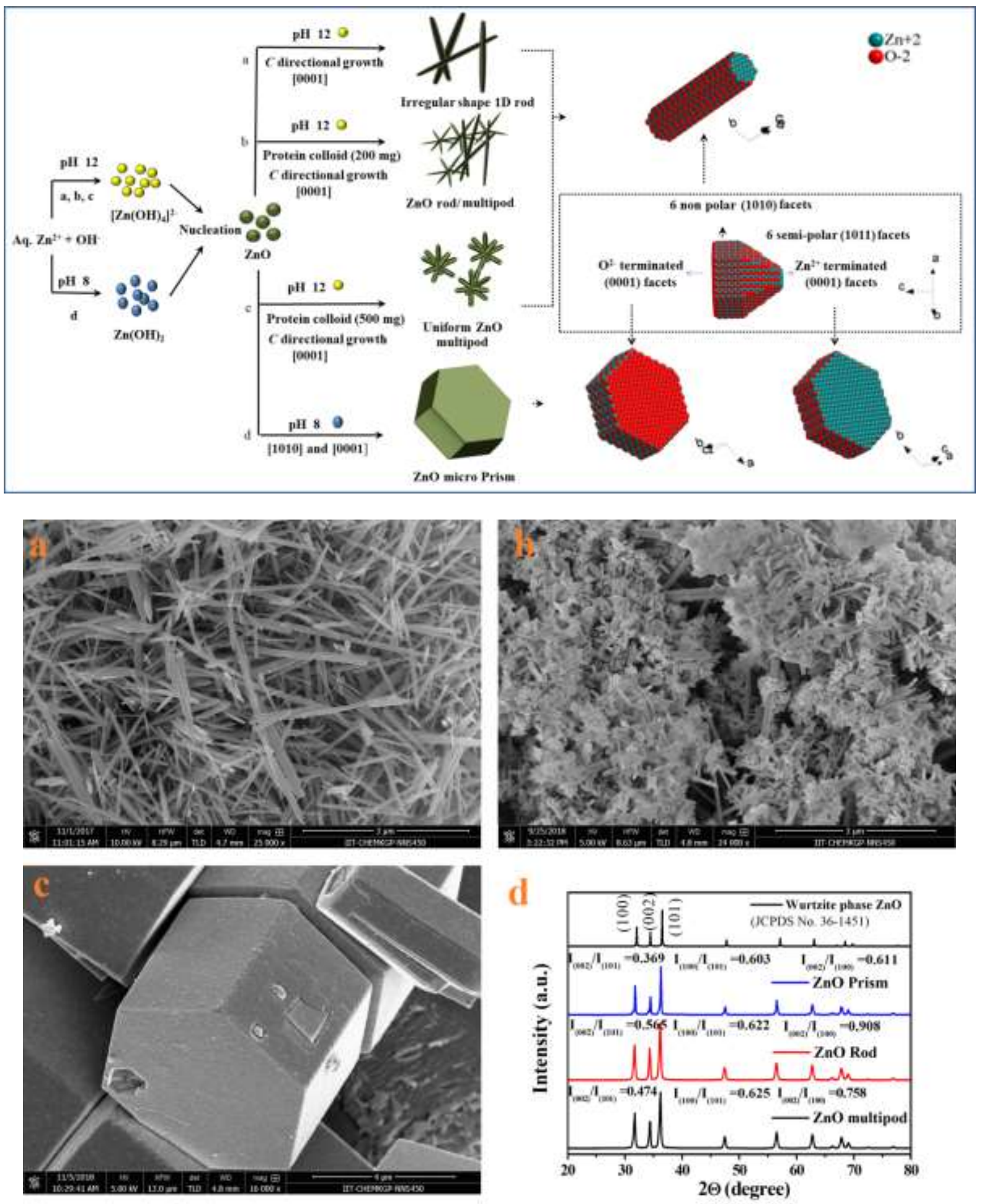

Figure S1. FESEM images of prepared $\mathrm{ZnO}$ (a) in absence of protein colloid, $\mathrm{pH} 12$ (b) in presence of protein colloid (200 mg), $\mathrm{pH} \mathrm{12,} \mathrm{(c)} \mathrm{in} \mathrm{absence} \mathrm{of} \mathrm{protein} \mathrm{colloid,} \mathrm{pH} 8$ and (d) their respective powder XRD patterns. 

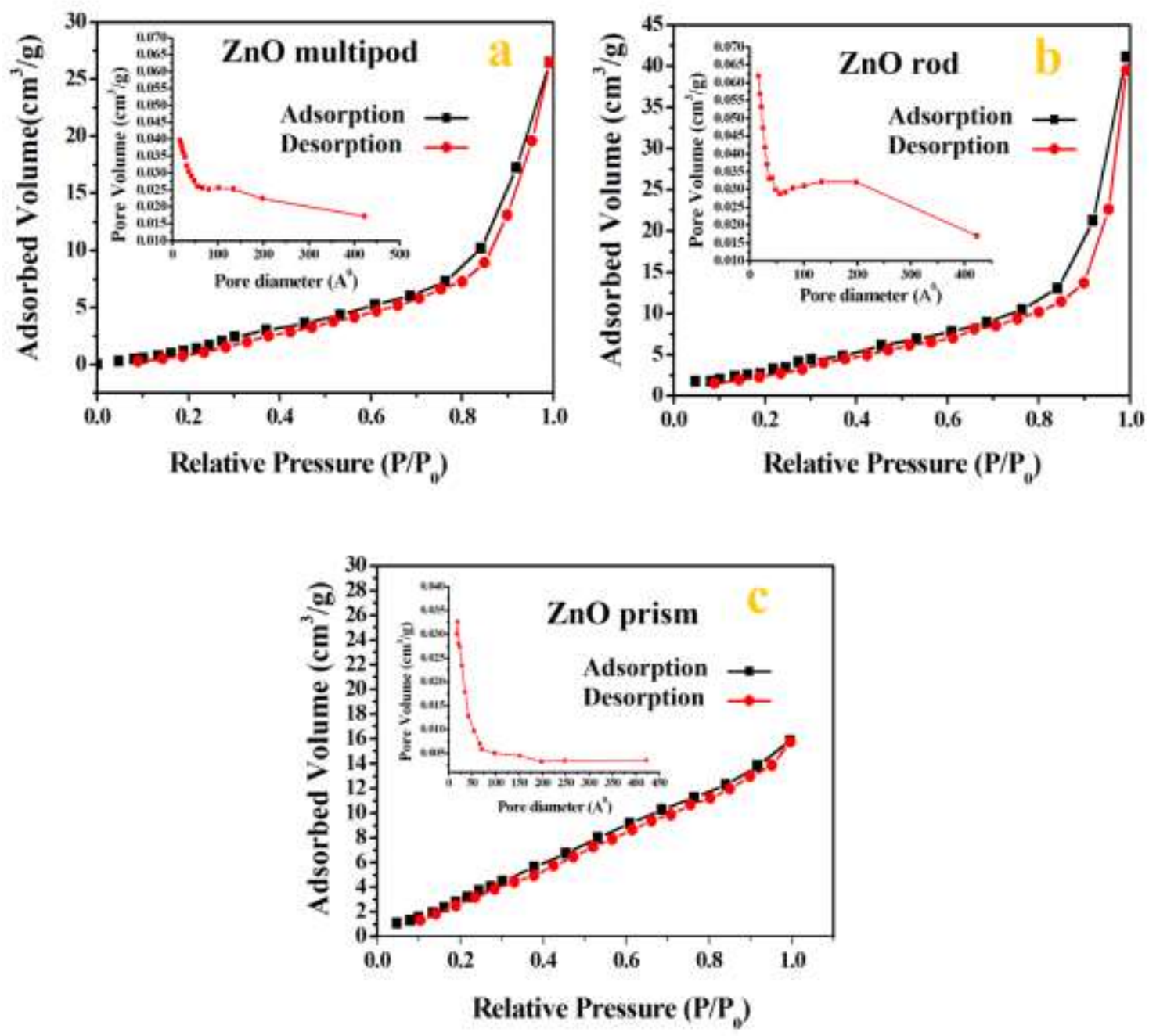

Figure S2. Nitrogen sorption isotherms of (a) $\mathrm{ZnO}$ multipod, (b) $\mathrm{ZnO}$ rod, and (c) $\mathrm{ZnO}$ prism (inset showing pore distribution curve of each $\mathrm{ZnO}$ structure).

Table S1. Physicochemical properties of (a) ZnO multipod, (b) $\mathrm{ZnO}$ rod, and (c) $\mathrm{ZnO}$ prsim.

\begin{tabular}{llll}
\hline Sample & $\begin{array}{l}\text { SBET } \\
\left(\mathrm{m}^{2} / \mathrm{g}\right)\end{array}$ & $\begin{array}{l}\text { Total pore volume } \\
\left(\mathrm{cm}^{3} / \mathrm{g}\right)\end{array}$ & $\begin{array}{c}\text { Average pore size } \\
(\mathrm{nm})\end{array}$ \\
\hline $\mathrm{ZnO}$ multipod & 22.7 & 0.03 & 5.6 \\
$\mathrm{ZnO}$ rod & 34.3 & 0.09 & 9.1 \\
$\mathrm{ZnO}$ prism & 11.2 & 0.01 & 3.7 \\
\hline
\end{tabular}



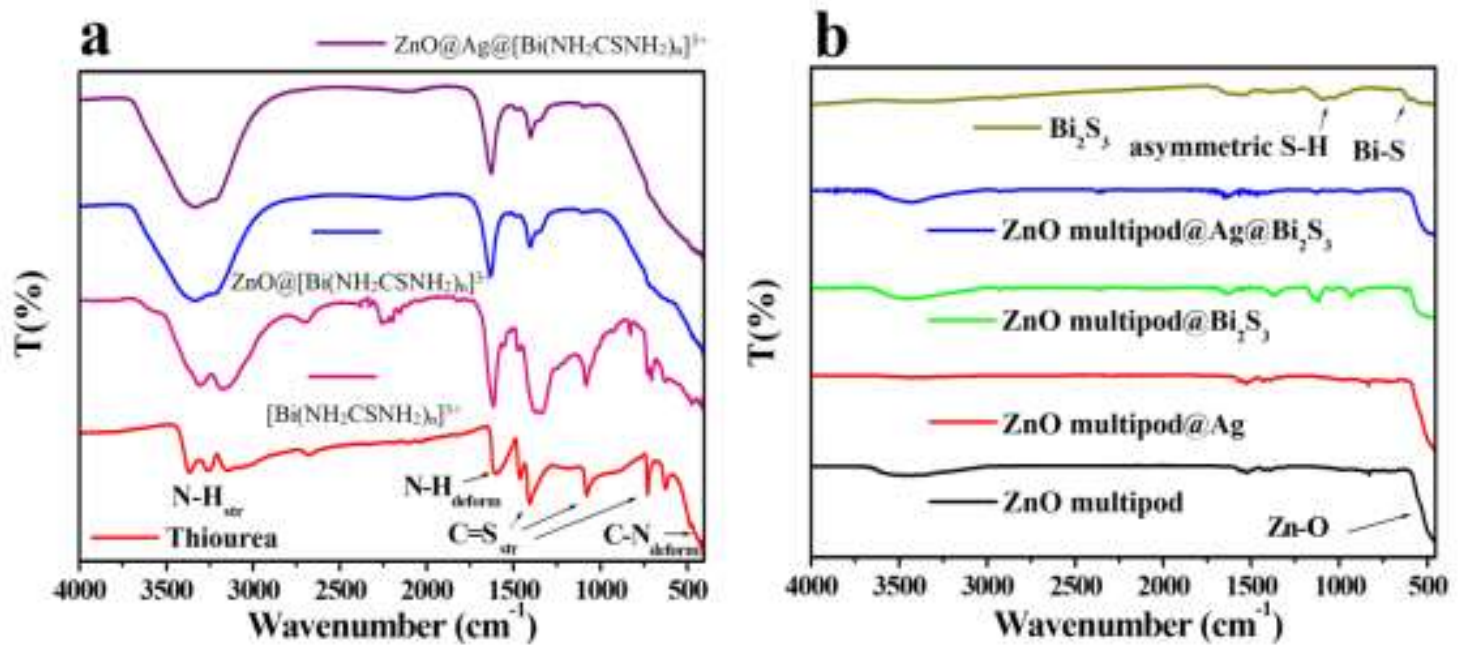

Figure S3. (a) FTIR spectra recorded in ethanol dispersion for the $\mathrm{ZnO}$ multipod and $\mathrm{ZnO}$ multipod @ Ag after adsorption of $\left[\mathrm{Bi}\left(\mathrm{NH}_{2} \mathrm{CSNH}_{2}\right)_{n}\right]^{3+}$ complex and comparison with the FTIR spectra of thio-urea and $\left[\mathrm{Bi}\left(\mathrm{NH}_{2} \mathrm{CSNH}_{2}\right)_{\mathrm{n}}\right]^{3+}$ complex. (b) FTIR spectra of the solid $\mathrm{ZnO}$ multipod, $\mathrm{Bi}_{2} \mathrm{~S}_{3}, \quad \mathrm{ZnO}$ multipod@Ag, $\mathrm{ZnO}$ multipod@ $\mathrm{Bi}_{2} \mathrm{~S}_{3}$, and $\mathrm{ZnO}$ multipod@Ag@ $\mathrm{Bi}_{2} \mathrm{~S}_{3}$.

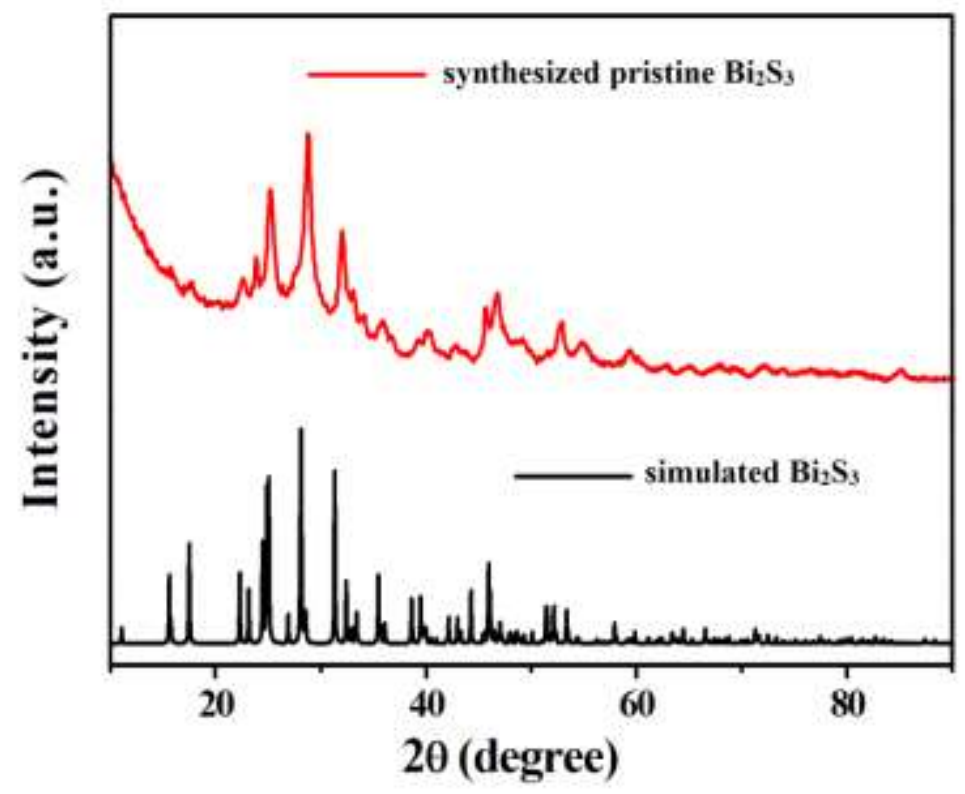

Figure S4. PXRD pattern of synthesized $\mathrm{Bi}_{2} \mathrm{~S}_{3}$ and compared with simulated XRD pattern of orthorhombic $\mathrm{Bi}_{2} \mathrm{~S}_{3}$. 

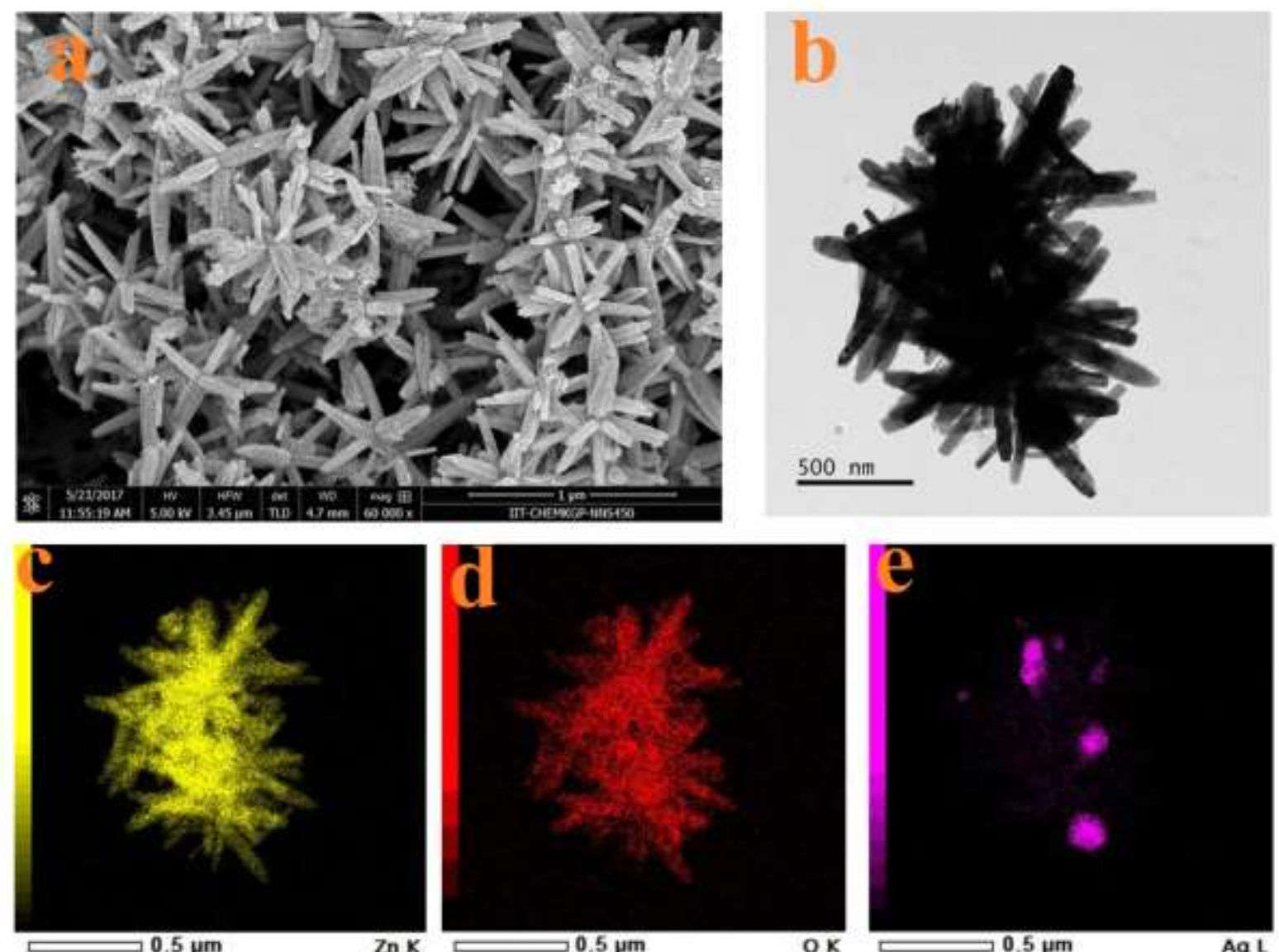

Figure S5. (a) FESEM images, (b) TEM images of the $\mathrm{ZnO}$ multipod@ Ag with elemental mapping images of (c) Zn, (d) O, (e) Ag in the hybrid.
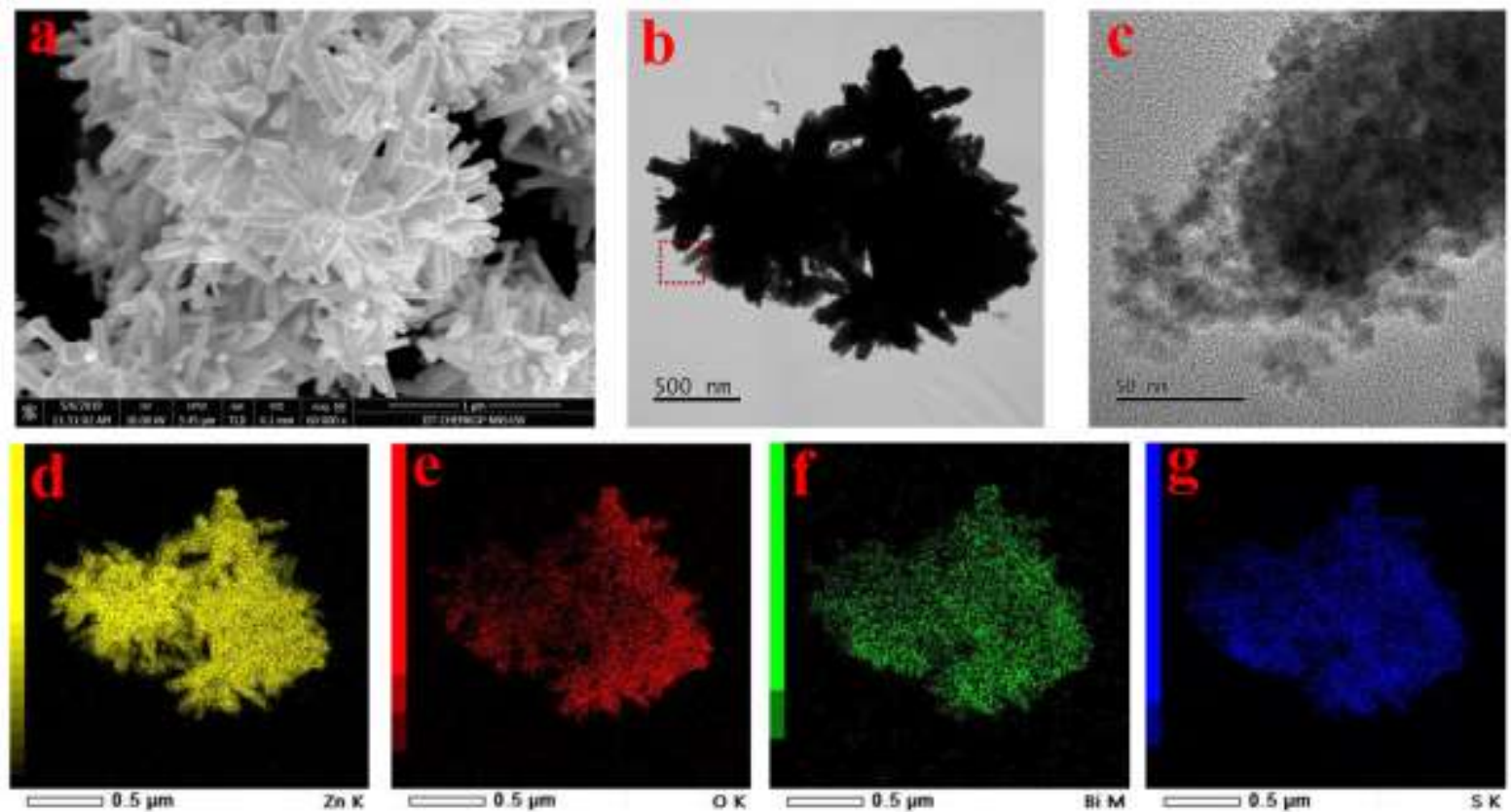

Figure S6. (a) FESEM, (b) TEM, (c) HRTEM images of the $\mathrm{ZnO}$ multipod@ $\mathrm{Bi}_{2} \mathrm{~S}_{3}$ with elemental mapping images of (d) $\mathrm{Zn}$, (e) $\mathrm{O}$, (f) $\mathrm{Bi}$, and (g) $\mathrm{S}$ in the hybrid. 

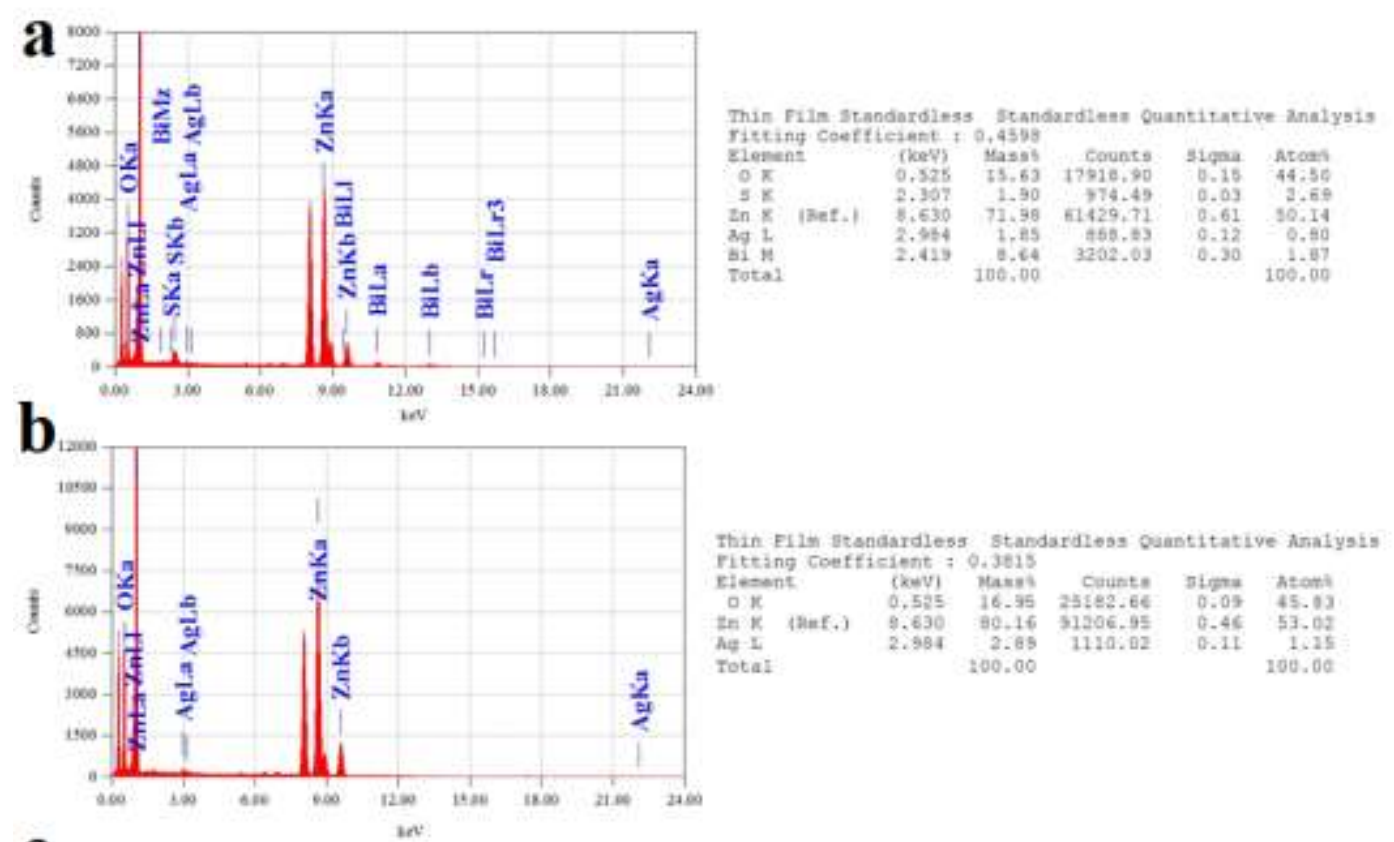

$\mathbf{c}_{z}$

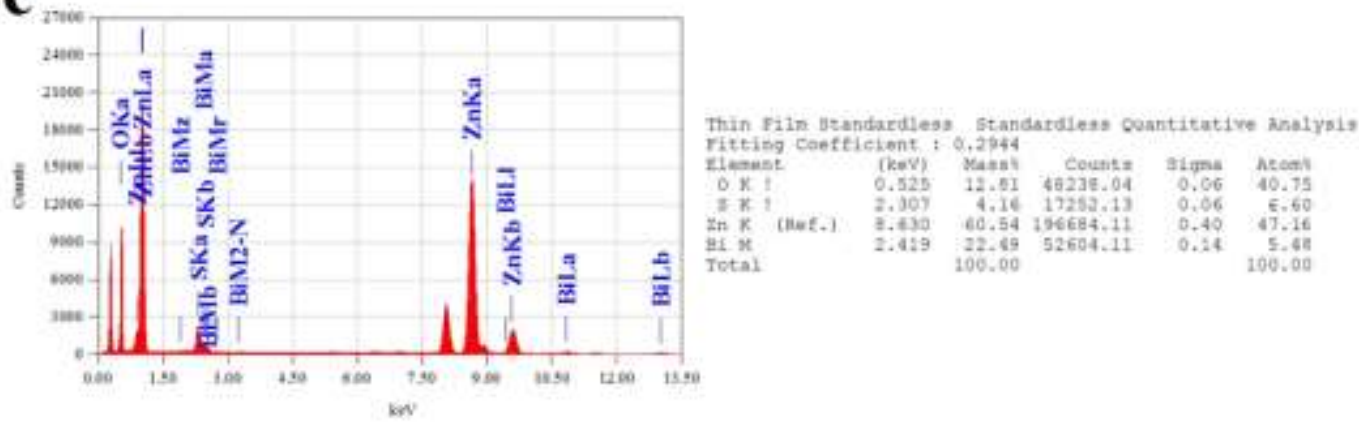

Figure S7. EDAX spectra of the (a) ZnO multipod@ $\mathrm{Ag} @ \mathrm{Bi}_{2} \mathrm{~S}_{3}$, (b) $\mathrm{ZnO}$ multipod @ $\mathrm{Ag}$, and (c) ZnO multipod@ $\mathrm{Bi}_{2} \mathrm{~S}_{3}$ shown in Figure 3e and Figure S6b, S7b and table in right showing chemical composition of mass $(\%) /$ atomic $(\%)$ of the elements present in that particular hybrid structure.
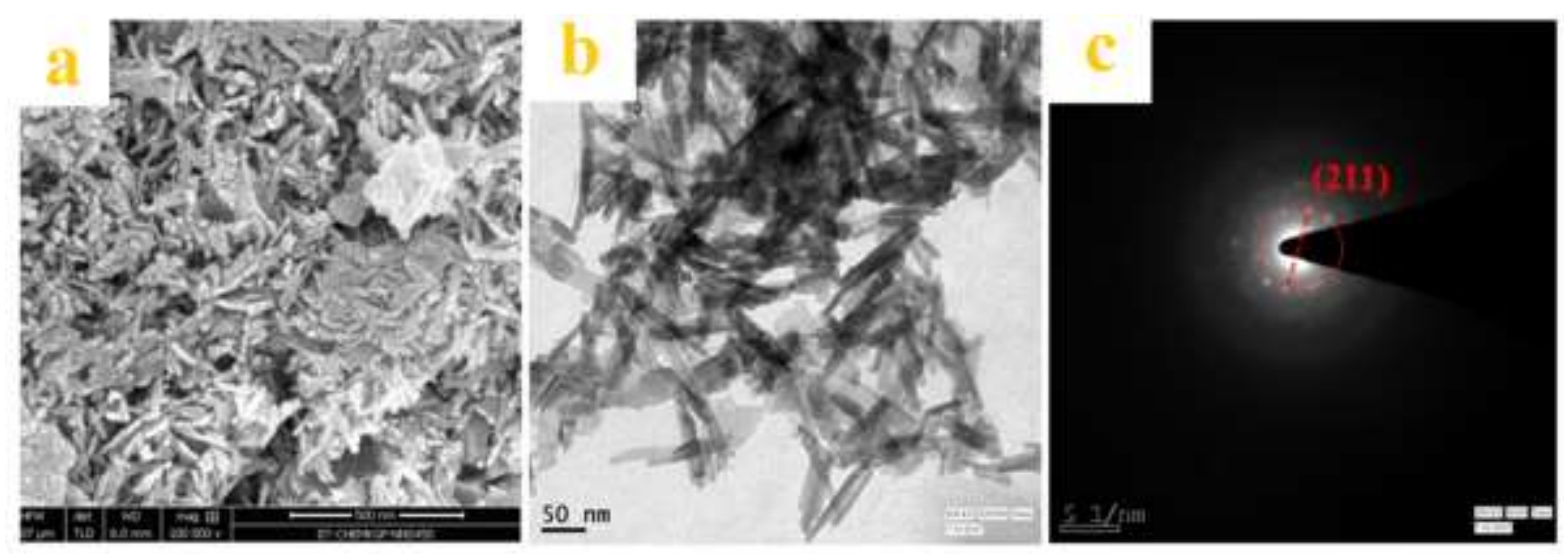

Figure S8. (a) FESEM, (b) HRTEM images of the pristine $\mathrm{Bi}_{2} \mathrm{~S}_{3}$, and (c) SAED pattern is showing polycrystalline nature of $\mathrm{Bi}_{2} \mathrm{~S}_{3}$. 


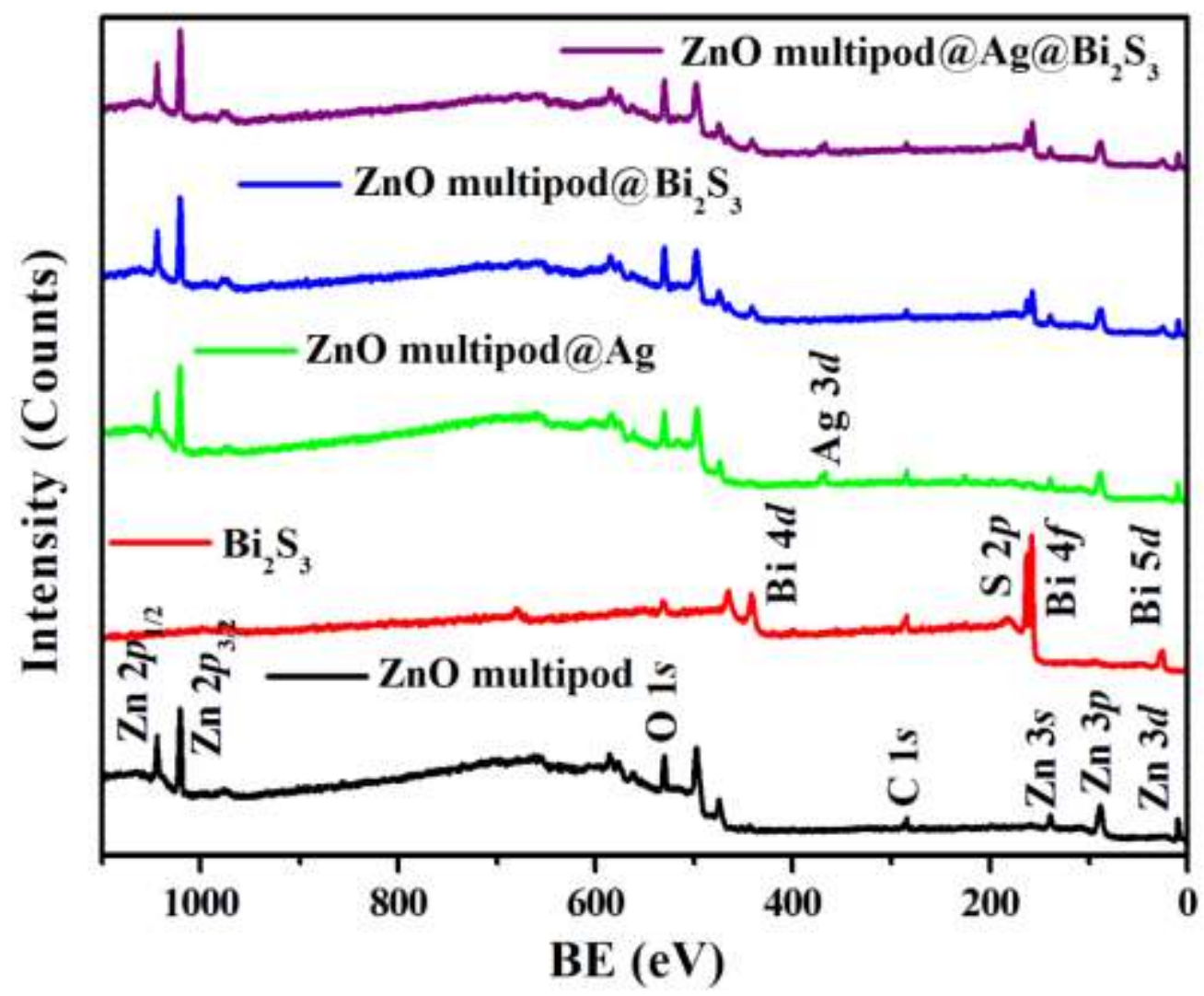

Figure S9. XPS survey image of $\mathrm{ZnO}$ multipod, $\mathrm{Bi}_{2} \mathrm{~S}_{3}, \mathrm{ZnO}$ multipod@ $\mathrm{Ag}, \mathrm{ZnO}$ multipod@Bi $\mathrm{S}_{3}$, and $\mathrm{ZnO}$ multipod@ $\mathrm{Ag} @ \mathrm{Bi}_{2} \mathrm{~S}_{3}$.

Table S2. Chemical composition (atomic \%) of the elements exists in the hybrid structure.

\begin{tabular}{|c|c|c|c|c|c|c|}
\hline Analysis & Sample & $\mathrm{Zn}$ & $\mathrm{O}$ & $\mathrm{Ag}$ & $\mathrm{Bi}$ & $\mathrm{S}$ \\
\hline \multirow{3}{*}{ XPS } & ZnOmultipod@Ag@ $\mathrm{Bi}_{2} \mathrm{~S}_{3}$ & 38.2 & 43.1 & 2.9 & 7.6 & 10.9 \\
\hline & ZnOmultipod@Ag & 50.02 & 45.83 & 4.15 & - & - \\
\hline & $\mathrm{ZnO}$ multipod@ $@ \mathrm{Bi}_{2} \mathrm{~S}_{3}$ & 43.16 & 37.75 & - & 7.48 & 11.60 \\
\hline
\end{tabular}



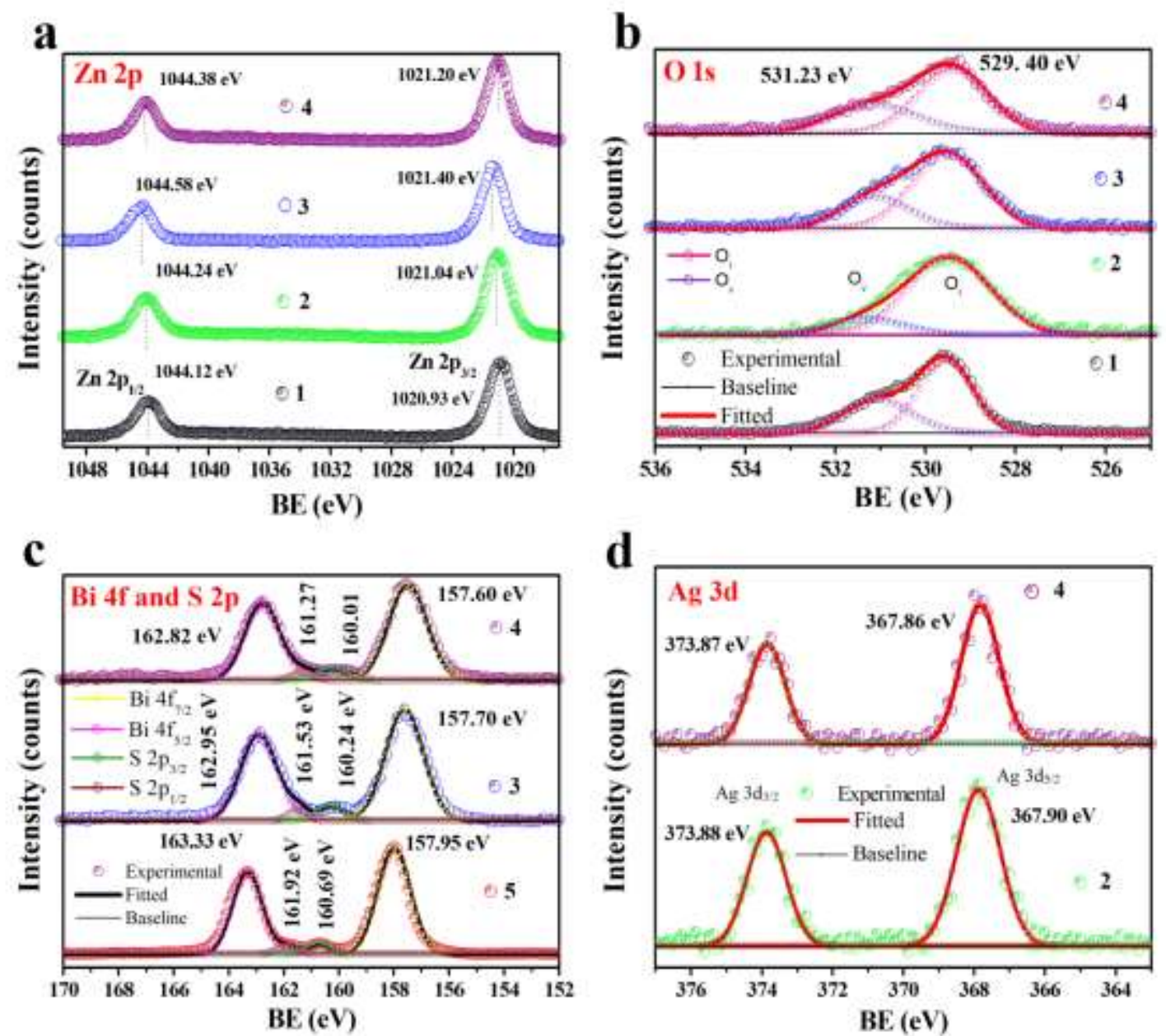

Figure S10. High-resolution XPS images of (a) Zn 2p and (b) O 1s, (c) Bi 4f and S 2p (d) Ag 3d for (1) pristine $\mathrm{ZnO}$ multipod, (2) ZnO multipod@ $\mathrm{Ag}$, (3) $\mathrm{ZnO}$ multipod@ $\mathrm{Bi}_{2} \mathrm{~S}_{3}$, (4) $\mathrm{ZnO}$ multipod@Ag@ $\mathrm{Bi} 2 \mathrm{~S}_{3}$, and (5) pristine $\mathrm{Bi}_{2} \mathrm{~S}_{3}$.

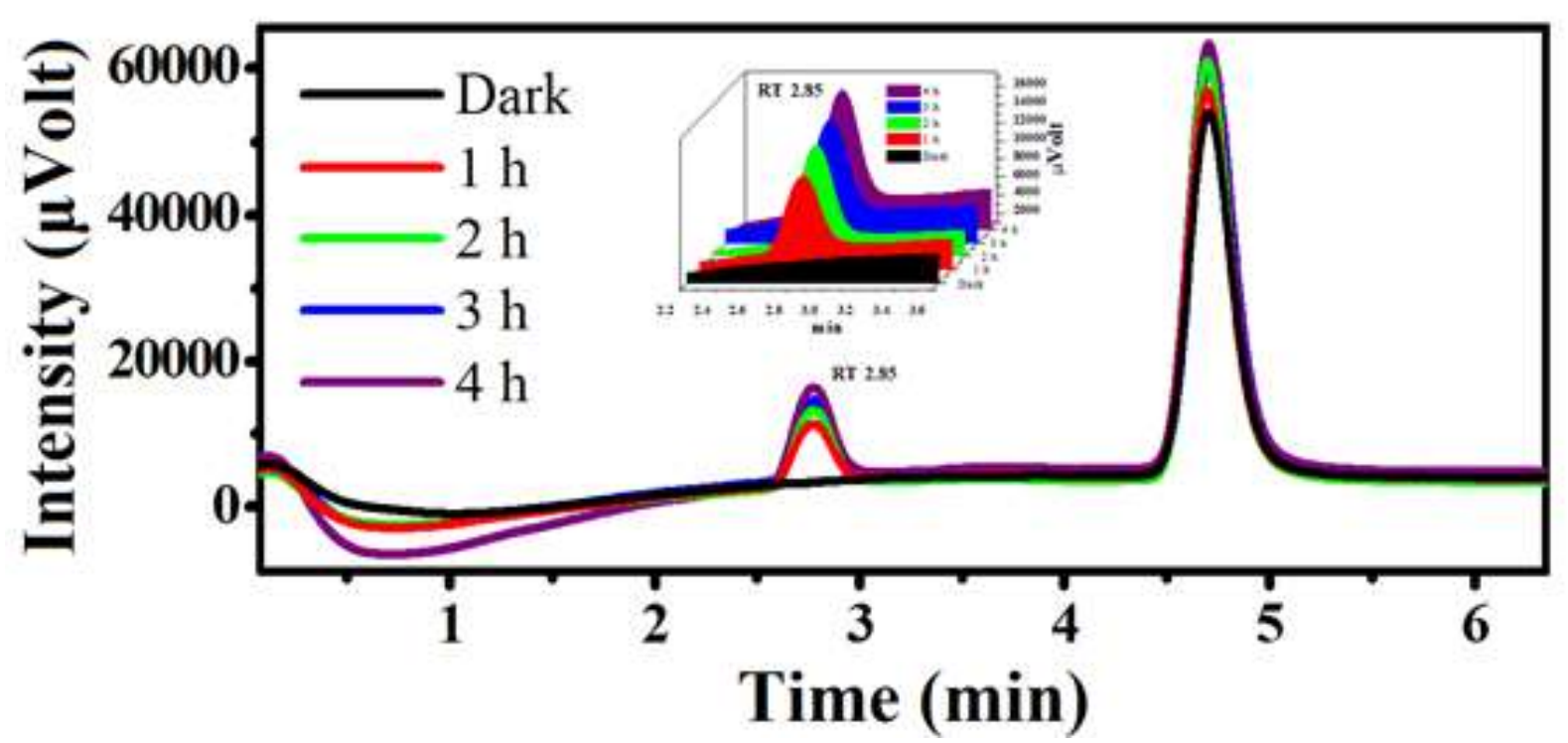

Figure S11. Gas chromatogram of the gaseous products produced in presence of $\mathrm{ZnO}$ multipod@Ag@ $\mathrm{Bi}_{2} \mathrm{~S}_{3}$. (Inset showing production of $\mathrm{H}_{2}$ monitored at the retention time of $2.85 \mathrm{~min}$ in the chromatogram) 


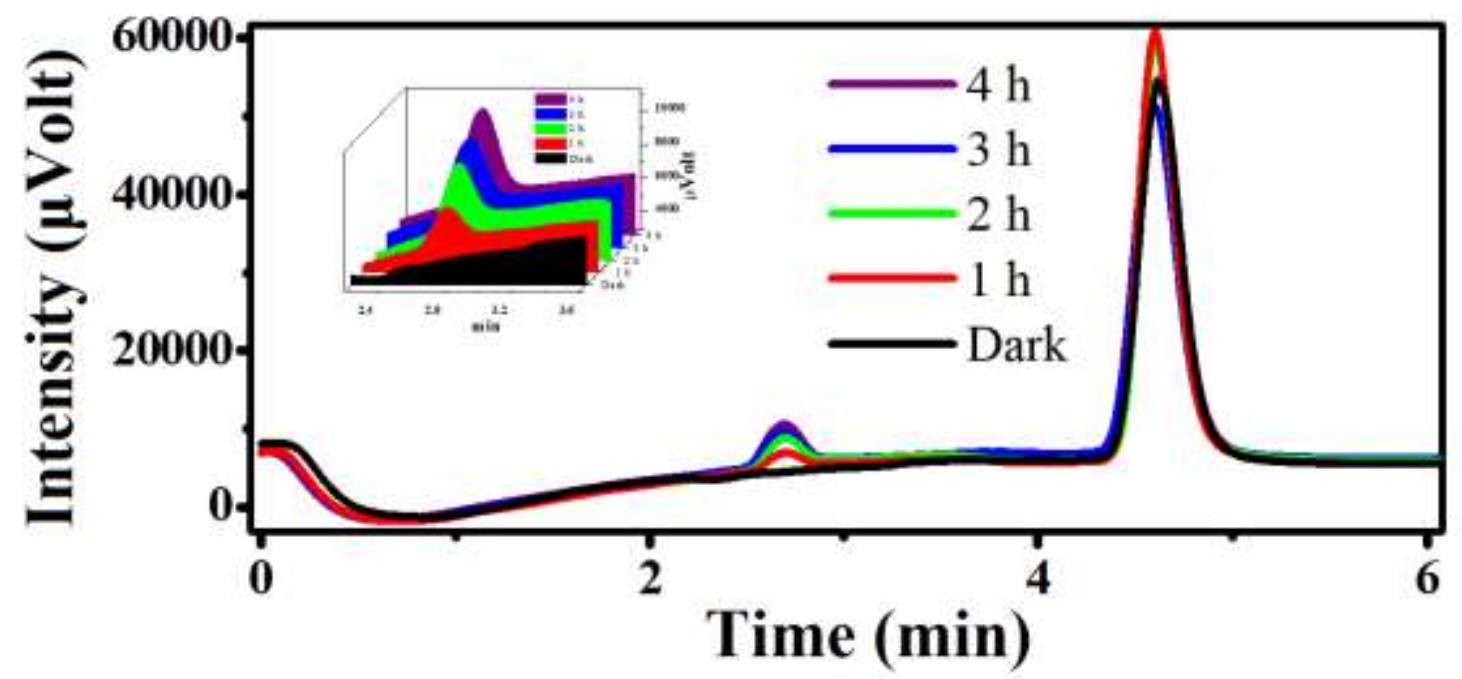

Figure S12. Gas chromatogram of the gaseous products produced in presence of $\mathrm{ZnO}$ multipod@ $\mathrm{Bi}_{2} \mathrm{~S}_{3}$. (Inset showing production of $\mathrm{H}_{2}$ monitored at the retention time of $2.85 \mathrm{~min}$ in the chromatogram)

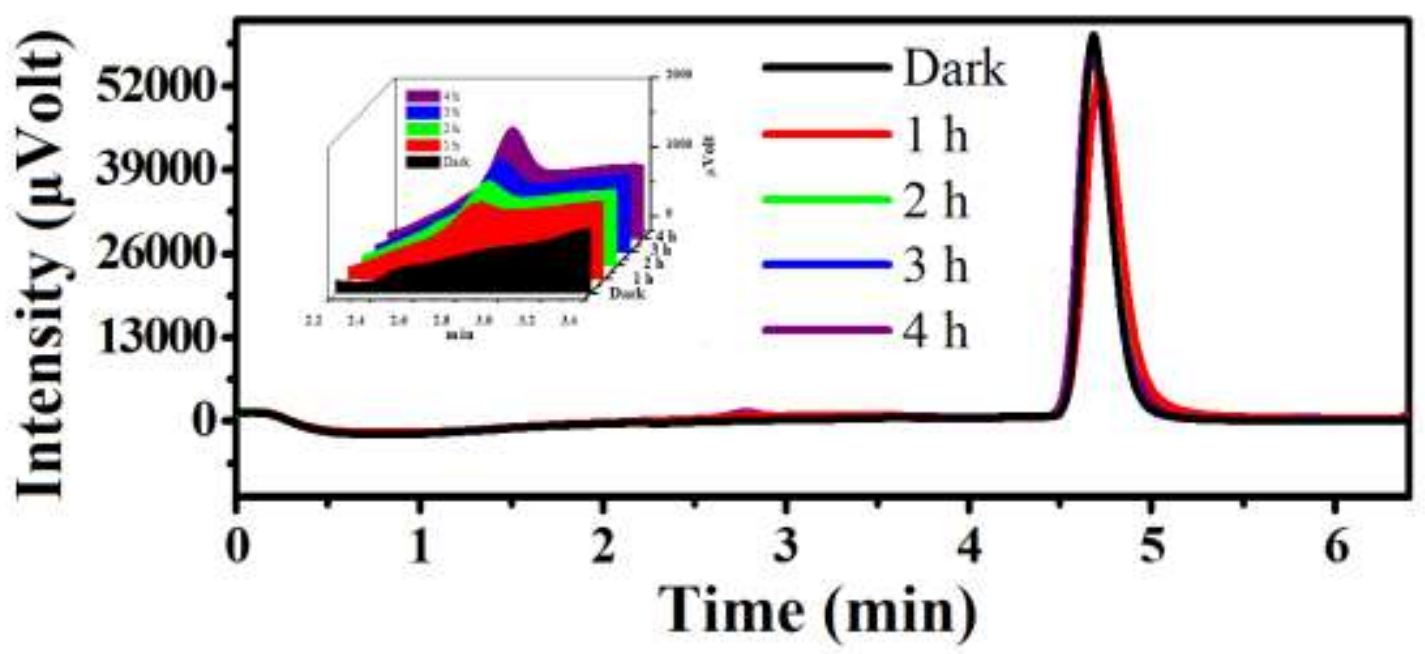

Figure S13: Gas chromatogram of the gaseous products produced in presence of $\mathrm{ZnO}$ multipod. (Inset showing production of $\mathrm{H}_{2}$ monitored at the retention time of $2.85 \mathrm{~min}$ in the chromatogram). 


\section{Measurement of the intensity of $250 \mathrm{~W}$ high pressure $\mathrm{Hg}$ lamp using potassium ferrioxalate as an actinometer: ${ }^{1-3}$}

The photon flux of the lamp (high pressure $250 \mathrm{~W} \mathrm{Hg}$ lamp) used in this photocatalytic study was measured by following a standard procedure utilizing potassium ferrioxalate as the actinometer. In this method, initially $10 \mathrm{ml}\left(\mathrm{V}_{1}\right)$ of $0.006 \mathrm{M}$ solution of potassium ferrioxalate was taken in a $30 \mathrm{ml}$ vial (pyrex) and placed $5 \mathrm{~cm}$ away from the light source. The solution $\left(\mathrm{V}_{1}\right)$ was then irradiated under stirring condition by the light source, where a pyrex glass jacket (inner diameter: $5 \mathrm{~cm}$ and outer diameter: $8 \mathrm{~cm}$ ) was used with water circulation to cool the lamp. After $1 \mathrm{~min}, 1 \mathrm{ml}\left(\mathrm{V}_{2}\right)$ of the irradiated solution was transferred into a $10 \mathrm{ml}$ $\left(\mathrm{V}_{3}\right)$ volumetric flask containing a mixture of $4 \mathrm{ml}$ of $0.1 \% 1,10$ - phenanthroline ethanolic solution and $0.5 \mathrm{ml}$ of buffer solution (stock solution: $82 \mathrm{~g} \mathrm{NaOAc}, 10 \mathrm{ml}$ conc. $\mathrm{H}_{2} \mathrm{SO}_{4}$, diluted to $1 \mathrm{~L}$ with distilled water) which was then diluted to the mark by distilled water. A reference was also prepared in the same way except that it has not been irradiated. Both solutions are kept in the dark for an hour until full colour of the Fe(III) complex was achieved. Then, absorption spectra of these solutions were recorded by using UV-Vis spectrophotometer. Then the absorbance of the first $\left(A_{t}\right)$ minus that of the second $\left(A_{r}\right)$ sample is measured at $510 \mathrm{~nm}\left(1 \mathrm{~cm}\right.$ path length, $\left.\varepsilon_{510 \mathrm{~nm}}=11100 \mathrm{dm}^{3} \mathrm{~mol}^{-1} \mathrm{~cm}^{-1}\right)$. The intensity $\left(\mathrm{I}_{0}\right)$ was calculated from the following eq. (1).

$$
\mathrm{I}_{0}=N_{A} \frac{\left(A_{t}-A_{r}\right) \times V_{1} \times 10^{-3} \times V_{3}}{\Phi_{\lambda} \times \varepsilon_{510} \times V_{2} \times \mathbf{l} \times \mathbf{t}} \text { Einstein } \mathrm{s}^{-1}
$$

$\mathrm{A}_{\mathrm{t}}=$ Absorbance of the irradiated sample at time $\mathrm{t}=0.898$

$\mathrm{A}_{\mathrm{r}}=$ Absorbance of the non-irradiated/reference sample $=0.336$

$1=$ optical path length $=1 \mathrm{~cm}$

$\mathrm{V}_{1}=10 \mathrm{ml}$

$\mathrm{V}_{2}=1 \mathrm{ml}$

$\mathrm{V}_{3}=10 \mathrm{ml}$

$\Phi_{365 \mathrm{~nm}}=1.16$, and $\varepsilon_{510 \mathrm{~nm}}$ for $1 \mathrm{~cm}$ path length $=11100 \mathrm{dm}^{3} \mathrm{~mol}^{-1} \mathrm{~cm}^{-1}$

Photon flux $=4.38 \times 10^{16}$ Einstein $\mathrm{s}^{-1}$

Area of light exposure $=5 \mathrm{~cm}^{2}$

Hence, $\mathrm{I}_{0}=$ Photon flux per unit area $=0.88 \times 10^{16}$ Einstein $\mathrm{s}^{-1} \mathrm{~cm}^{-2}=0.0048 \mathrm{~W} / \mathrm{cm}^{2}$ 


\section{Number of $\mathrm{H}_{2}$ molecule produced: ${ }^{4}$}

The corresponding amount of hydrogen gas produced in moles per hour $=2.187 \times 10^{-6} \mathrm{~mole}^{-}$

${ }^{1}$ (obtained from GC) for $\mathrm{ZnO} @ \mathrm{Ag} @ \mathrm{Bi}_{2} \mathrm{~S}_{3}$

1 mole gas $=6.023 \times 10^{23}$ molecules

$2.187 \times 10^{-6}$ moles will have $=6.023 \times 10^{23} \times 2.187 \times 10^{-6}$ number of $\mathrm{H}_{2}$ molecules in $1 \mathrm{~h}$.

$\mathrm{H}_{2}$ molecule $($ per $s)=6.023 \times 10^{23} \times 2.187 \times 10^{-6} /(60 \times 60 \mathrm{~s})$

$=3.65 \times 10^{14}\left(\mathrm{~s}^{-1}\right)$

\section{Apparent quantum yield (AQY \%): 5}

Apparent Qumntum yield $=\frac{2 \times n H_{2}}{\text { Number of incident photons }\left(\frac{I A \lambda}{h c}\right)} \times 100 \%$

Where, $n H_{2}$ is the number of $\mathrm{H}_{2}$ molecule produced per second, $I$ is the incident solar irradiance $\left(\mathrm{W} / \mathrm{cm}^{2}\right)$ over the irradiated area $A\left(\mathrm{~cm}^{2}\right), \lambda$ is the wavelength of the present study, $h$ Planck's and $c$ is the speed of light. In order to get value of Efficiency study, we have measured AQY at the wavelength $365 \mathrm{~nm}$ to as shown below.

$\mathrm{nH}_{2}=\mathbf{3 . 6 5} \times \mathbf{1 0}^{14}\left(\mathrm{~s}^{-1}\right)$

$\mathrm{I}=0.0048 \mathrm{~W} / \mathrm{cm}^{2}$

$\mathrm{A}=7.28 \mathrm{~cm}^{2}$

Thus,

$A Q Y$ at $365 \mathrm{~nm}$

$=\frac{2 \times 3.65 \times 10^{14}}{\left(0.0048 \times 7.28 \times 365 \times 10^{-9}\right) /\left(6.627 \times 10^{-34} \times 3 \times 10^{8}\right.}\left(\frac{S^{-1}}{\frac{W}{\frac{c m^{2}}{J . m . s . s^{-1}}}}\right) \times 100 \%$

$=1.13 \%$ 

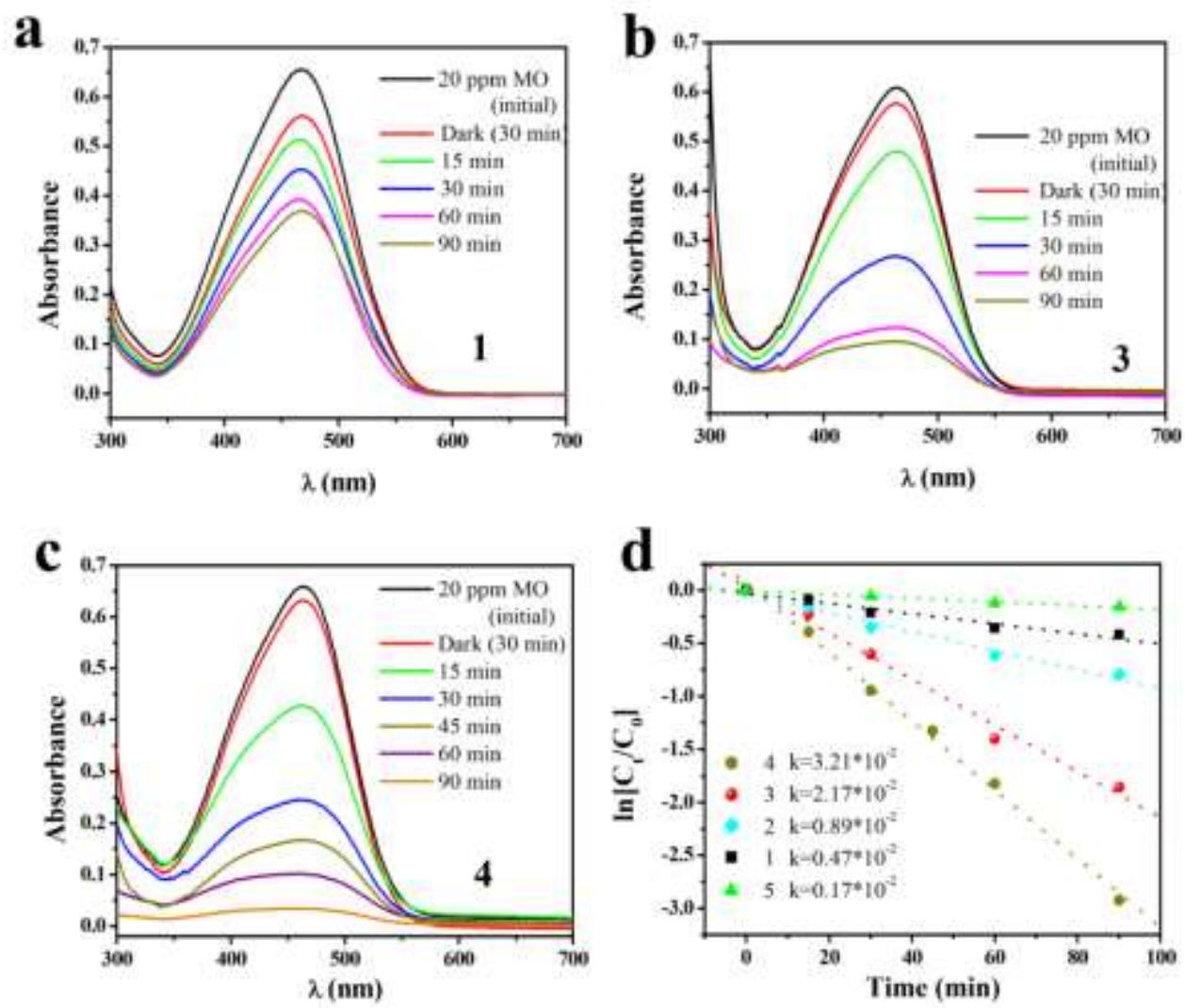

Figure S14. UV-visible absorption spectra $v s$ light irradiation time of $20 \mathrm{ppm} \mathrm{MO}$ in presence of (a) $\mathrm{ZnO}$ multipod@ $\mathrm{Ag} @ \mathrm{Bi}_{2} \mathrm{~S}_{3}$, (b) $\mathrm{ZnO}$ multipod@ $\mathrm{Bi}_{2} \mathrm{~S}_{3}$, (c) $\mathrm{ZnO}$ multipod (light source: $250 \mathrm{~W}$ high pressure $\mathrm{Hg}$ lamp, catalytic dose: $1 \mathrm{~g} / \mathrm{L}$, ambient condition), and (f) first order kinetics plots for (1) $\mathrm{ZnO}$ multipod, (2) $\mathrm{ZnO}$ multipod@ $\mathrm{Ag}$, (3) $\mathrm{ZnO}$ multipod@ $\mathrm{Bi}_{2} \mathrm{~S}_{3}$, (4) $\mathrm{ZnO}$ multipod@Ag@Bi $\mathrm{S}_{3}$, and (5) $\mathrm{Bi}_{2} \mathrm{~S}_{3}$ towards the oxidation of methyl orange (inset showing rate constant value in $\mathrm{min}^{-1}$ ).

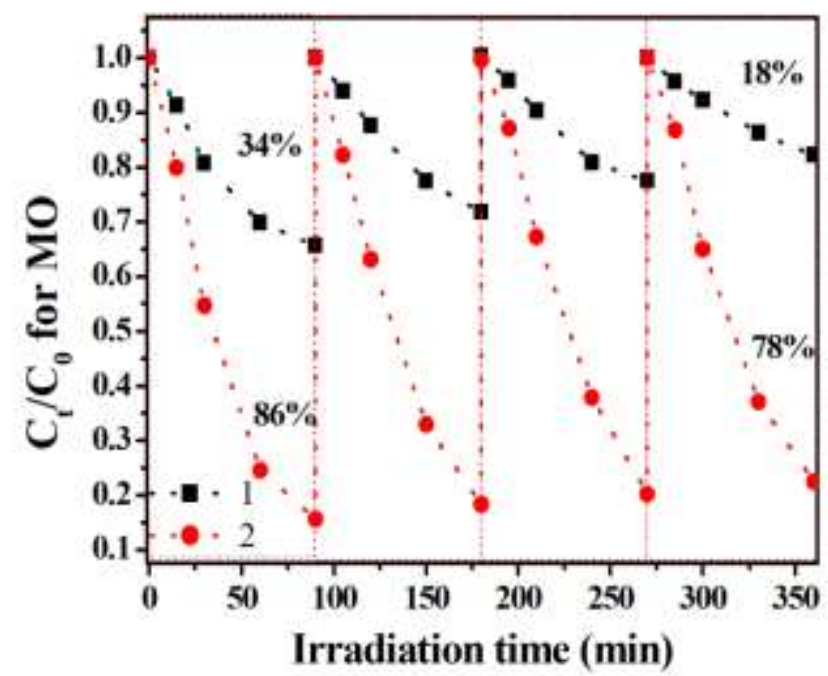

Figure S15. Photocatalytic cycle of (1) $\mathrm{ZnO}$ multipod, and (2) $\mathrm{ZnO}$ multipod@ $\mathrm{Bi}_{2} \mathrm{~S}_{3}$ for the degradation of MO (catalytic dose: $1 \mathrm{~g} / \mathrm{L}$, ambient condition) in presence of light $(250 \mathrm{~W}$ high pressure Hg lamp). 

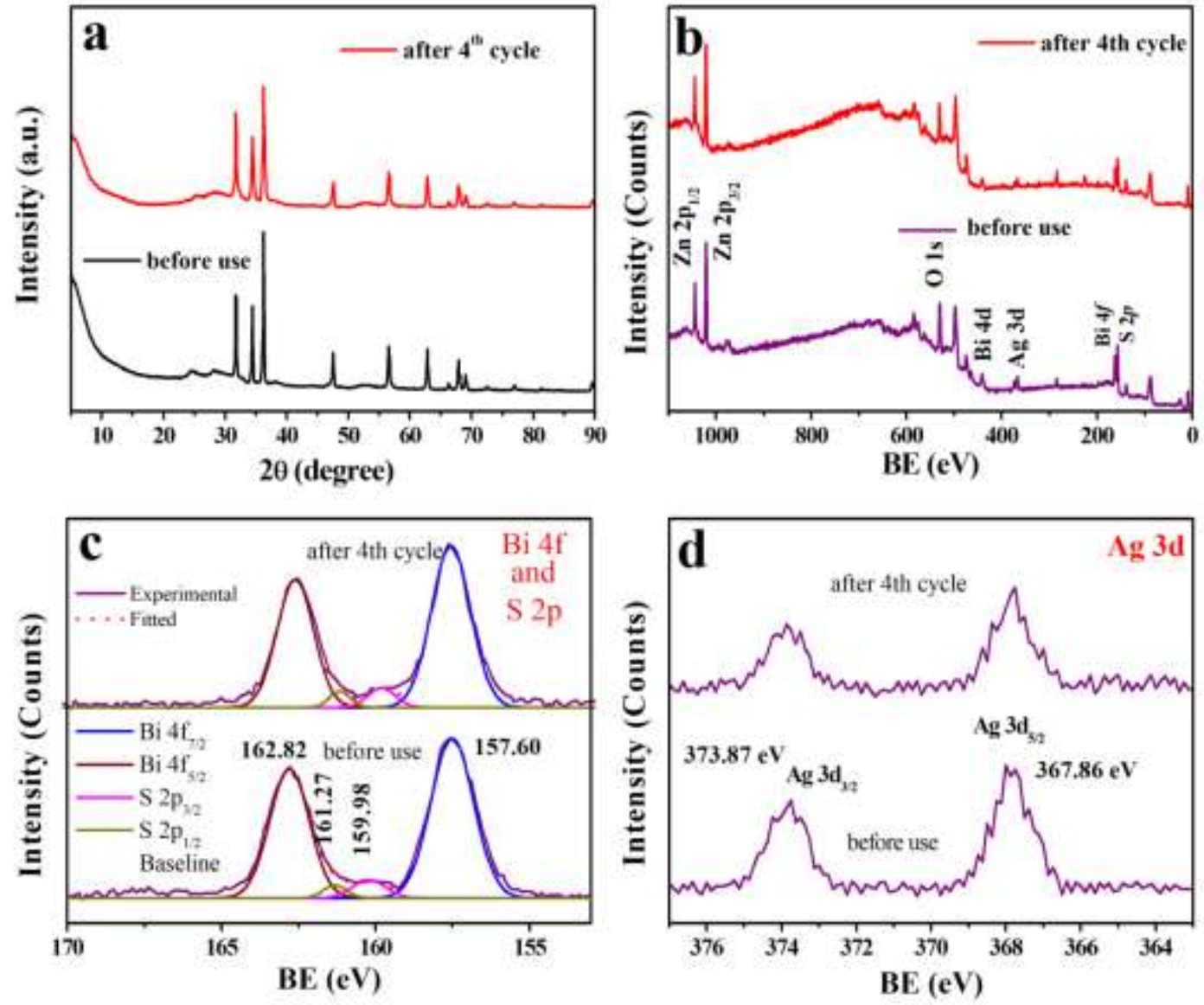

Figure S 16. (a) XRD pattern and (b) survey XPS images of the $\mathrm{ZnO}$ multipod@ $\mathrm{Ag} @ \mathrm{Bi}_{2} \mathrm{~S}_{3}$ before and after usage in photocatalytic degradation of MO. High resolution XPS images of (c) Bi 4f, S 2p, and (d) Ag $3 \mathrm{~d}$ of the ternary hybrids after $4^{\text {th }}$ cycle and comparison with the catalyst before use.

Table S3. Chemical composition (atomic \%) of the elements present in the $\mathrm{ZnO}$ multipod@Ag@ $\mathrm{Bi}_{2} \mathrm{~S}_{3}$ before and after use. ${ }^{\mathrm{a}}$

\begin{tabular}{|c|c|c|c|c|c|}
\hline Sample & $\operatorname{Zn}(\%)$ & $\mathbf{O}(\%)$ & $\operatorname{Ag}(\%)$ & $\operatorname{Bi}(\%)$ & $\mathrm{S}(\%)$ \\
\hline Before use & 38.2 & $\overline{43.1}$ & 2.9 & 7.6 & 10.9 \\
\hline After 4 th cycle & 37.8 & 42.2 & 2.1 & 6.5 & 11.4 \\
\hline
\end{tabular}

${ }^{a}$ calculated from XPS measurements. 

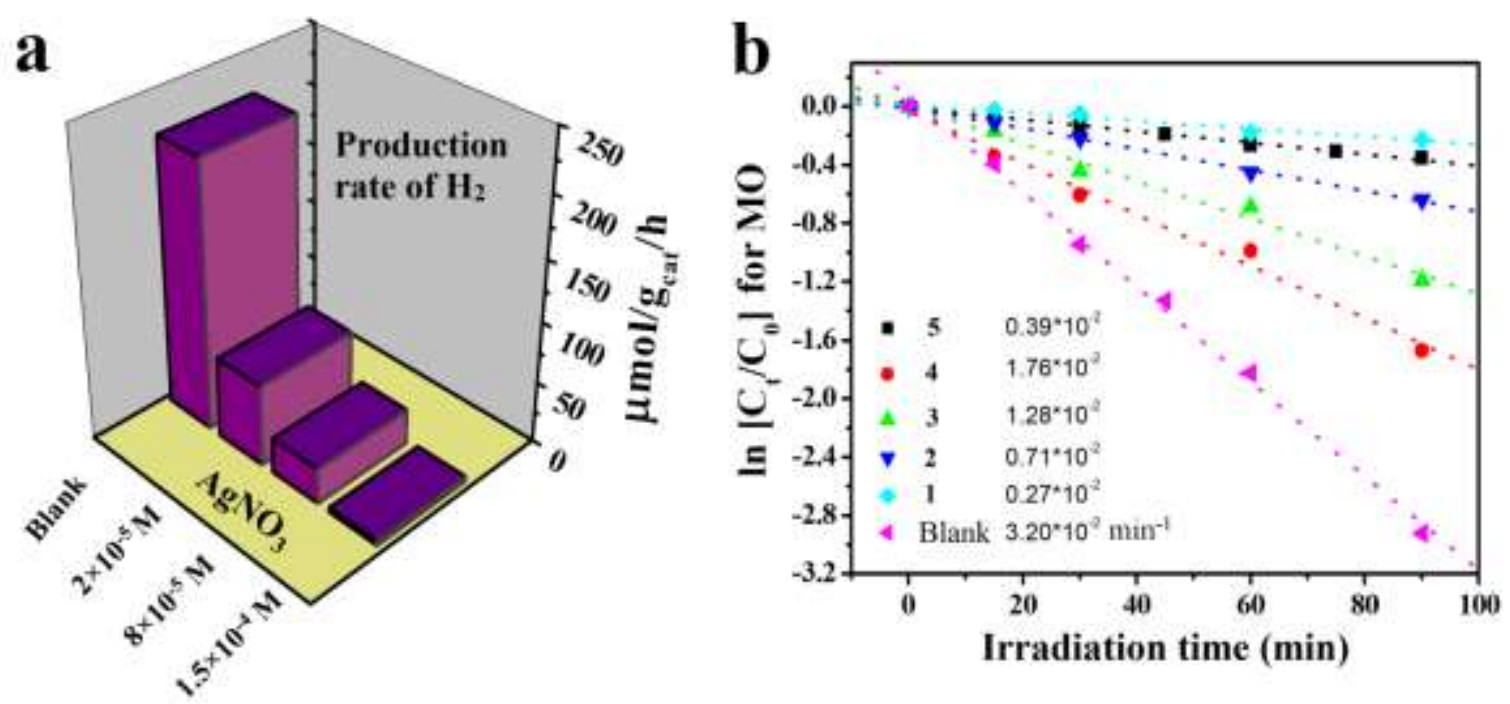

Figure S17. Chart showing photocatalytic $\mathrm{H}_{2}$ production rate of the $\mathrm{ZnO}$ multipod@ $\mathrm{Ag} @ \mathrm{Bi}_{2} \mathrm{~S}_{3}$ in presence of $\mathrm{AgNO}_{3}$ at concentration of (1) $1.5 \times 10^{-4} \mathrm{M}$, (2) $8 \times 10^{-5}$ $\mathrm{M}$, (3) $2 \times 10^{-5} \mathrm{M}$ (Conditions: $20 \mathrm{~mL}$ of $0.05 \mathrm{M} \mathrm{Na}_{2} \mathrm{~S}-0.1 \mathrm{M} \mathrm{Na}_{2} \mathrm{SO}_{3}$ aqueous solution; light source: $250 \mathrm{~W}$ high pressure $\mathrm{Hg}$ lamp; catalytic dose: $0.5 \mathrm{~g} / \mathrm{L}$; atmosphere: $\mathrm{Ar}$ ), and (b) comparison of apparent first order kinetics (inset showing rate constant value in $\mathrm{min}^{-1}$ ) of $\mathrm{MO}$ oxidation in presence of $\mathrm{ZnO}$ multipod@ $\mathrm{Ag} @ \mathrm{Bi}_{2} \mathrm{~S}_{3}$ with the addition of (1) isopropanol $\left(2 \times 10^{-4} \mathrm{M}\right)$ as an hydroxyl radical $(\cdot \mathrm{OH})$ scavengers, (2) Na 2 EDTA $\left(4 \times 10^{-4} \mathrm{M}\right)$ as hole $\left(\mathrm{h}^{+}\right)$ scavenger, (3) $\mathrm{AgNO}_{3}\left(4 \times 10^{-4} \mathrm{M}\right)$, and $(4) \mathrm{K}_{2} \mathrm{~S}_{2} \mathrm{O}_{8}\left(2 \times 10^{-4} \mathrm{M}\right)$ as an electron (e) scavenger, and (5) benzoquinone $\left(4 \times 10^{-4} \mathrm{M}\right)$ as an superoxide $\left(\mathrm{O}_{2}^{-}\right)$scavengers at ambient conditions under the irradiation of light ( $250 \mathrm{~W}$ high pressure $\mathrm{Hg}$ lamp).
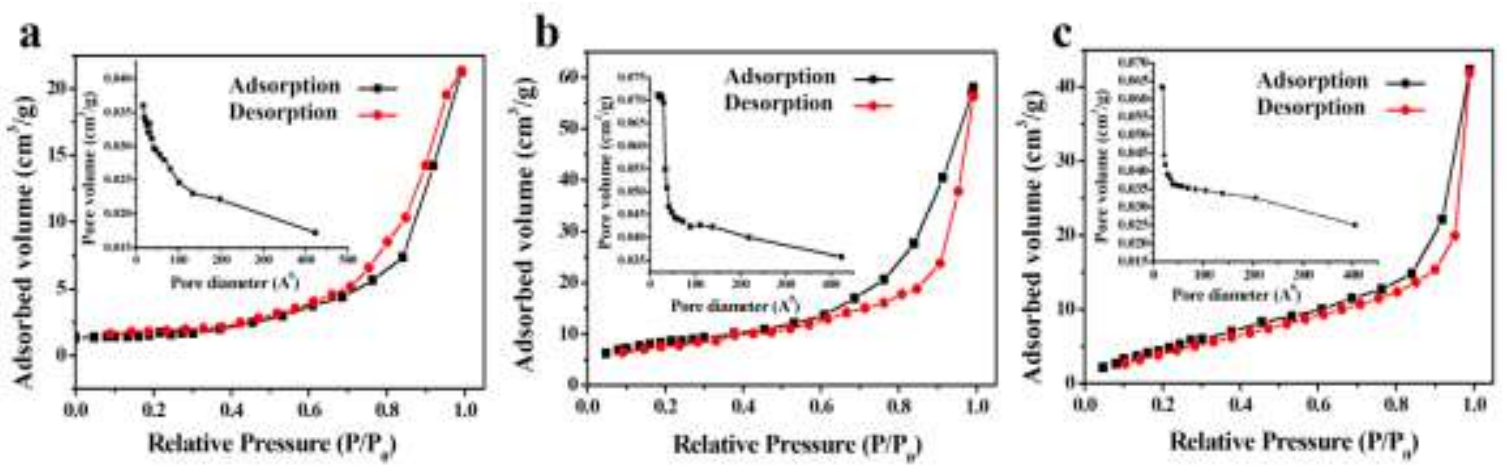

Figure S18. Nitrogen sorption isotherms measured for the (a) $\mathrm{ZnO}$ multipod@ $\mathrm{Ag}$, (c) $\mathrm{ZnO}$ multipod@ $\mathrm{Bi}_{2} \mathrm{~S}_{3}$, and (d) $\mathrm{ZnO} @ \mathrm{Ag} @ \mathrm{Bi}_{2} \mathrm{~S}_{3}$. 
Table S4. Physicochemical properties tabulated for the (a) $\mathrm{ZnO}$ multipod@ $\mathrm{Ag}$, (b) $\mathrm{ZnO}$ multipod@ $\mathrm{Bi}_{2} \mathrm{~S}_{3}$, and (c) $\mathrm{ZnO} @ \mathrm{Ag} @ \mathrm{Bi}_{2} \mathrm{~S}_{3}$.

\begin{tabular}{llll}
\hline Sample & $\begin{array}{l}\text { S } \\
\left(\mathrm{m}^{2} / \mathrm{g}\right)\end{array}$ & $\begin{array}{l}\text { Total pore volume } \\
\left(\mathrm{cm}^{3} / \mathrm{g}\right)\end{array}$ & $\begin{array}{c}\text { Average pore size } \\
(\mathrm{nm})\end{array}$ \\
\hline $\mathrm{ZnO}$ multipod@ $\mathrm{Ag}$ & 18.5 & 0.02 & 4.5 \\
$\mathrm{ZnO}$ & 0.07 & 7.1 \\
multipod@ $\mathrm{Bi}_{2} \mathrm{~S}_{3}$ & 41.8 & & 5.9 \\
$\mathrm{ZnO} @ \mathrm{Ag} @ \mathrm{Bi}_{2} \mathrm{~S}_{3}$ & 34.6 & 0.05 & 5.6 \\
$\mathrm{ZnO}$ multipod & 22.7 & 0.03 & 6.5 \\
$\mathrm{Bi}_{2} \mathrm{~S}_{3}$ & 49.1 & 0.08 & \\
\hline
\end{tabular}

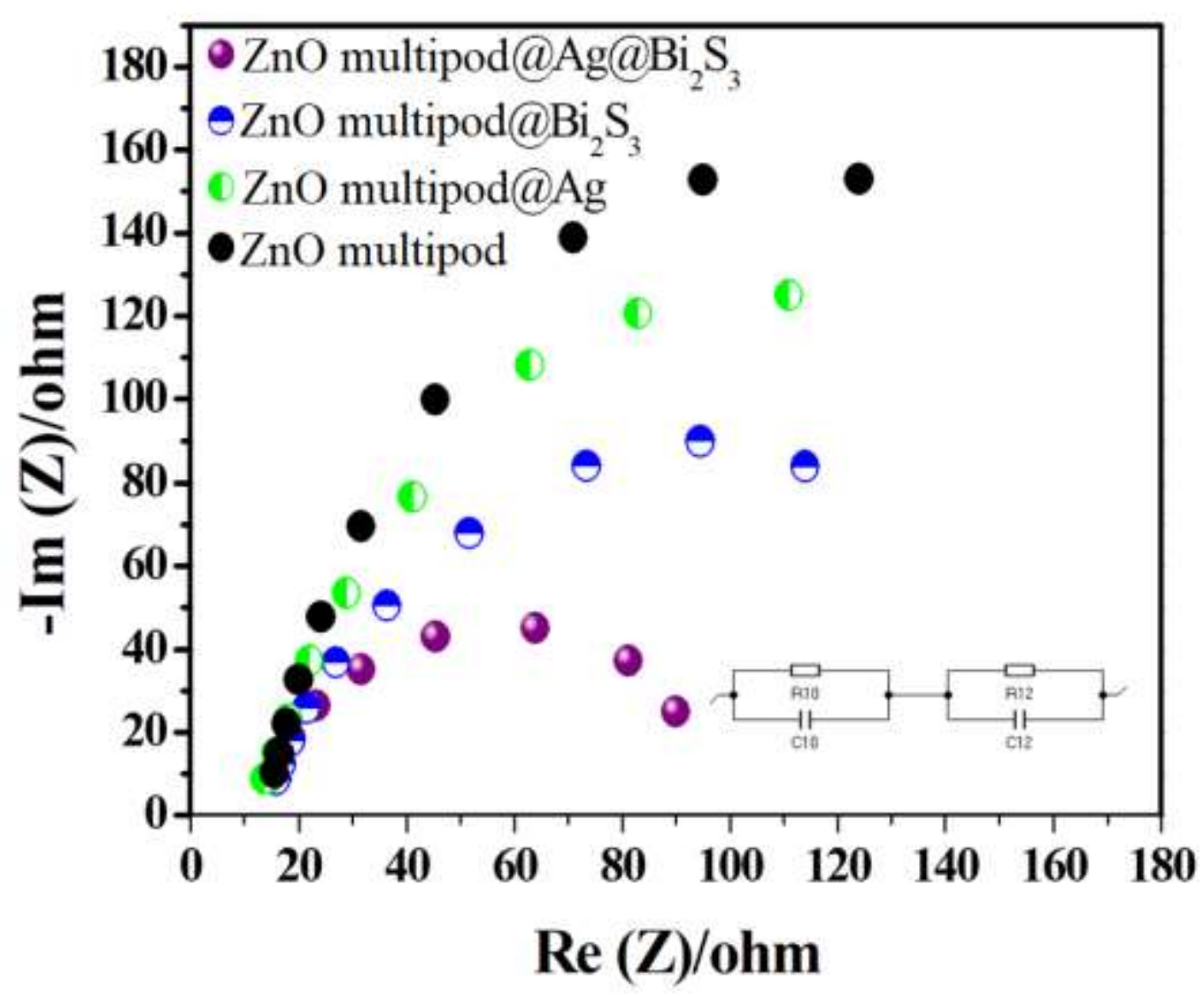

Figure S19. Electrochemical impedance spectra (EIS) measurements of the pristine $\mathrm{ZnO}$ multipod, ZnO multipod@ $\mathrm{Ag}, \mathrm{ZnO}$ multipod@ $\mathrm{Bi}_{2} \mathrm{~S}_{3}$, and $\mathrm{ZnO}$ multipod @ $\mathrm{Ag} @ \mathrm{Bi}_{2} \mathrm{~S}_{3}$ ternary heterostructure under light irradiation (300 W Xe lamp). 

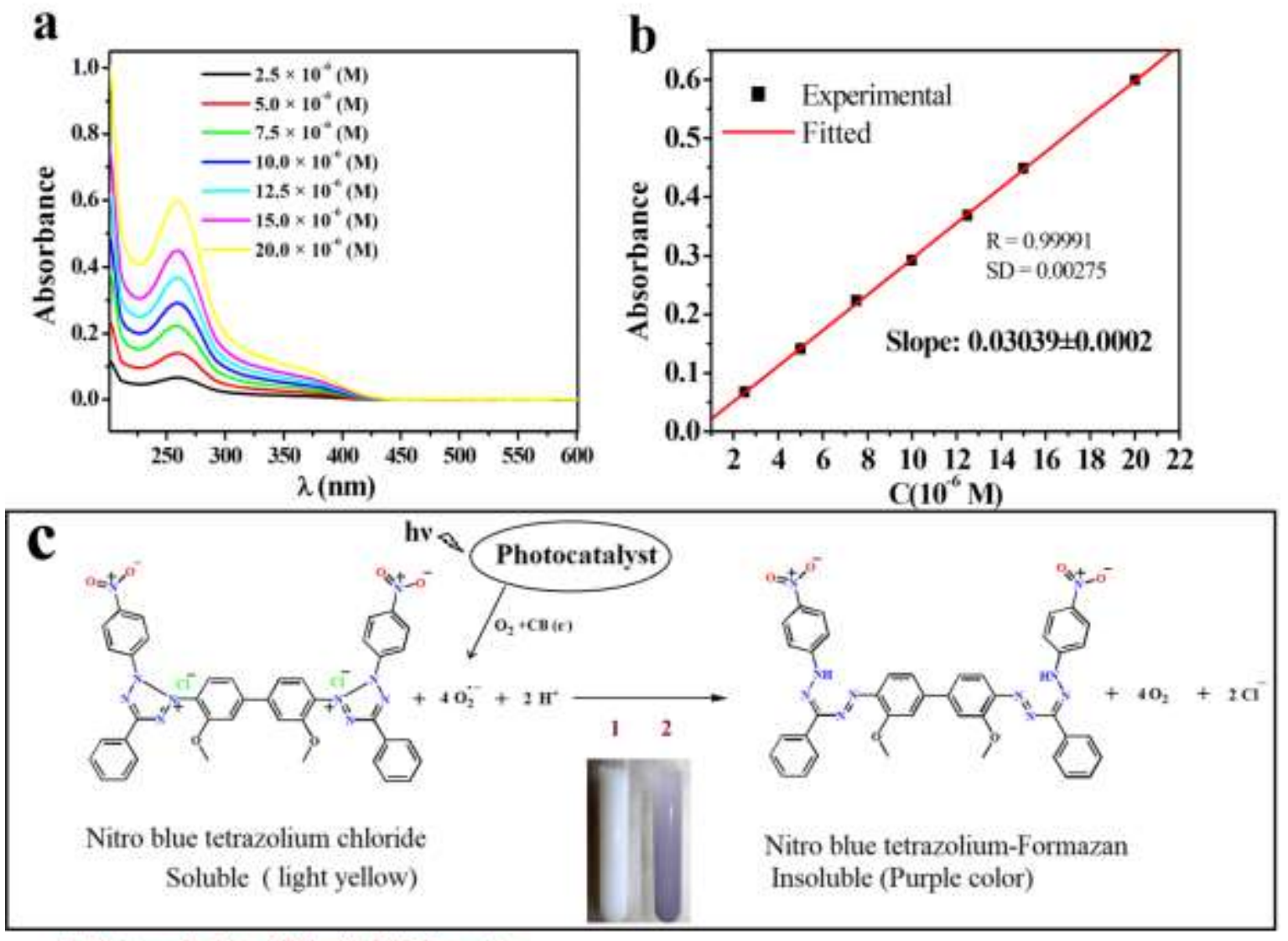

1. Photengraph of aq. NBT with ZnO dispersion
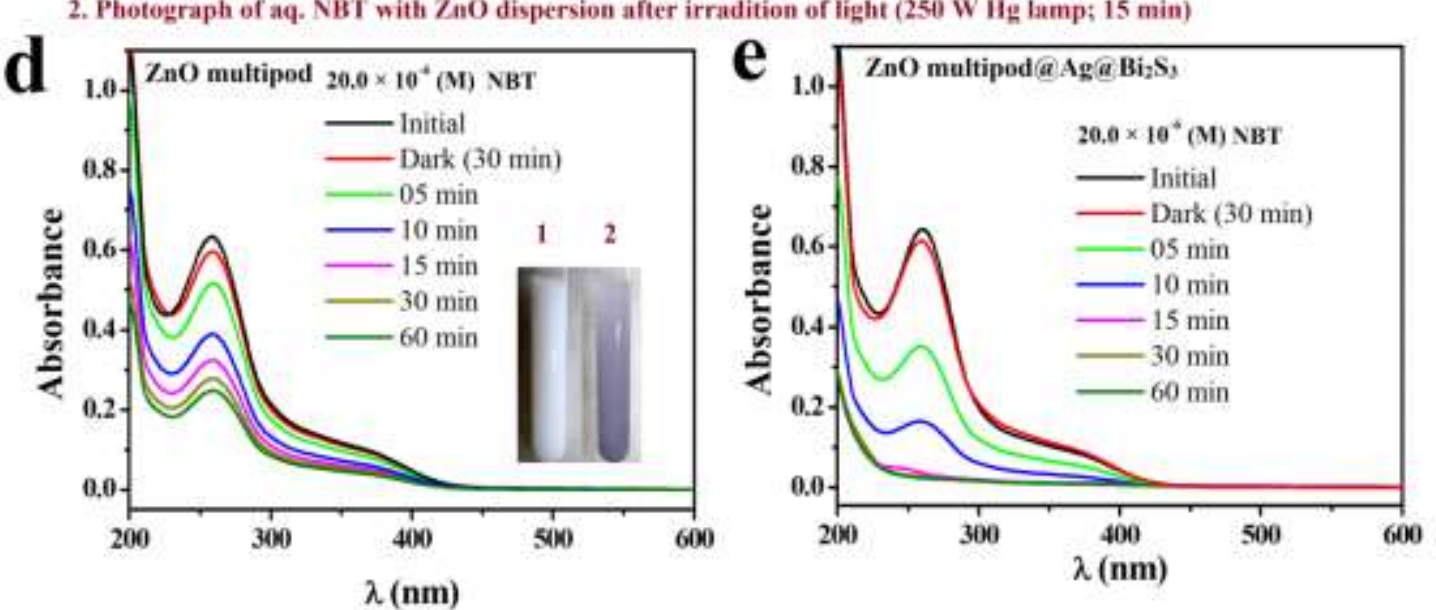

Figure S20. (a) UV-Visible absorption spectra of aqueous nitro blue tetrazolium chloride (NBT) at various concentrations $\left(2.5 \times 10^{-6}\right.$ to $\left.20 \times 10^{-6} \mathrm{M}\right)$, (b) a linear plot showing absorption vs $\mathrm{C}_{\mathrm{NBT}}$ (c) Photocatalytic production of $\mathrm{O}_{2}{ }^{--}$by $\mathrm{ZnO}$ detected by NBT method shown in photograph and reaction is showing 1 eqv. NBT reacts with 4 eqv superoxide forming formazan derivative: ( $\mathrm{ZnO}: 1 \mathrm{~g} \mathrm{~L}^{-1}$; light source: $250 \mathrm{~W}$ high pressure $\mathrm{Hg}$ lamp). Absorption spectra of remaining NBT with time during photocatalytic production of superoxide by (d) $\mathrm{ZnO}$ multipod, and (e) $\mathrm{ZnO}$ multipod@ $\mathrm{Ag} @ \mathrm{Bi}_{2} \mathrm{~S}_{3}$ (Conditions: $2 \times 10^{-5} \mathrm{M}$ aqueous NBT; catalytic dose: $1 \mathrm{~g} \mathrm{~L}^{-1}$; light source: $250 \mathrm{~W}$ high pressure $\mathrm{Hg}$ lamp; aerobic condition). 

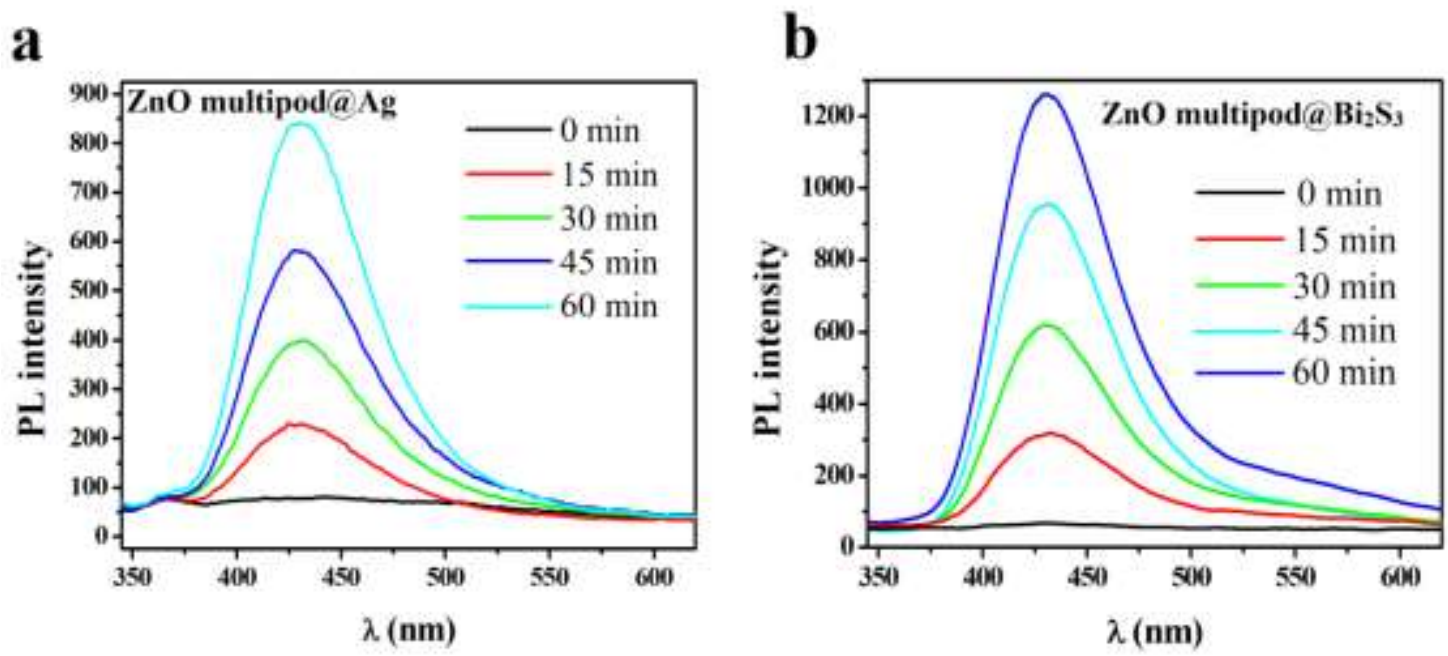

Figure S21. PL intensity $\left(\lambda_{\mathrm{ex}}=325 \mathrm{~nm}\right)$ of 2 hydroxyterepthalic acid in different time generated from adduct of hydroxyl radical with a probe terephthalic acid during photocatalytic production of hydroxyl radical by (a) $\mathrm{ZnO}$ multipod@ $\mathrm{Ag}$, (b) $\mathrm{ZnO}$ multipod@ $\mathrm{Bi}_{2} \mathrm{~S}_{3}$. (Conditions: $5 \times 10^{-3} \mathrm{M}$ aqueous terephthalic acid; catalytic dose: $1 \mathrm{~g} \mathrm{~L}^{-1}$; light source: $250 \mathrm{~W}$ high pressure $\mathrm{Hg}$ lamp; atmosphere: $\mathrm{N}_{2}$ ).

a

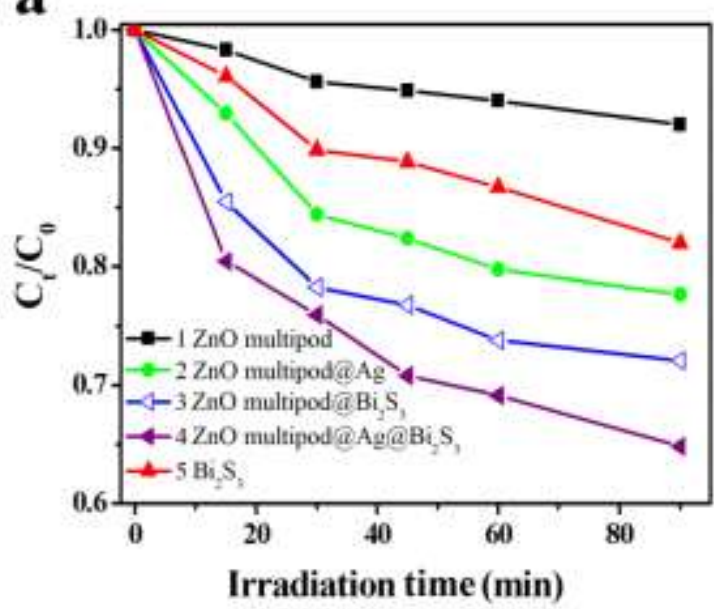

b

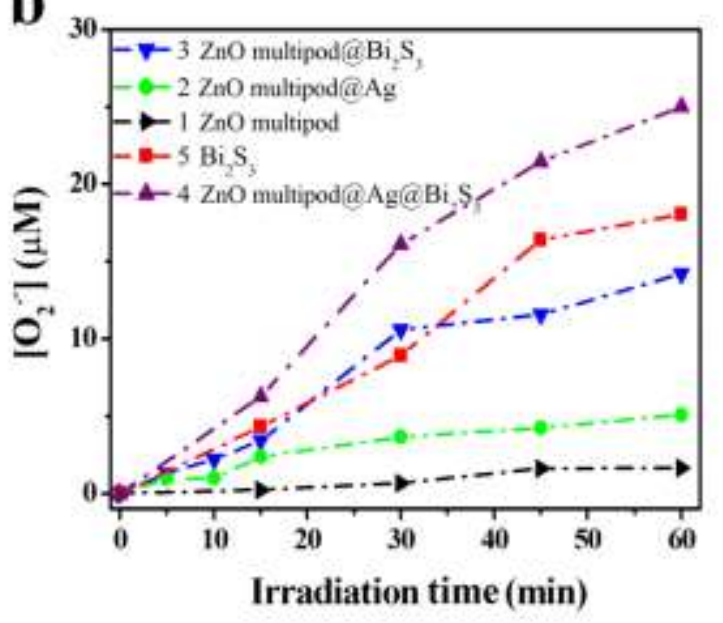

Figure S22. (a) $\mathrm{C}_{t} / \mathrm{C}_{0} v s$ time plot for the degradation of $\mathrm{MO}$ in presence of various photocatalyst (Condition: $20 \mathrm{ppm} \mathrm{MO}$; catalytic dose: $1 \mathrm{~g} \mathrm{~L}^{-1}$, light source: $250 \mathrm{~W}$ high pressure $\mathrm{Hg}$ lamp, $\lambda \geq 420 \mathrm{~nm}$; aerobic condition), and (b) a comparison of photocatalytic production of $\mathrm{O}_{2}{ }^{--}$by various photocatalysts is detected by NBT method. (Condition: $2 \times 10^{-5}$ $\mathrm{M}$ aqueous NBT; catalytic dose: $1 \mathrm{~g} \mathrm{~L}^{-1}$; light source: $250 \mathrm{~W}$ high pressure $\mathrm{Hg}$ lamp, $\lambda \geq 420$ $\mathrm{nm}$; aerobic condition). 


\section{References:}

1. Hatchard, C. G.; Parker. C. A. A new sensitive chemical actinometer II. Potassium ferrioxalate as a standard chemical actinometer. Proc. R. Soc. London, Ser. A, 1956, 235 , 518.

2. Ananthakrishnan, R.; Gazi, S. $\left[\mathrm{Ru}(\mathrm{bpy})_{3}\right]^{2+}$ aided photocatalytic synthesis of 2-arylpyridines via Hantzsch reaction under visible irradiation and oxygen atmosphere. Catal. Sci. Technol. 2012, 2, 1463.

3. Verma, N.; Ananthakrishnan, R. Riboflavin-immobilized $\mathrm{CeO}_{2}-\mathrm{RGO}$ nanohybrid as a potential photoredox catalyst for enhanced removal of organic pollutants under visible light. J. Phys. Chem. C 2020, 124, 404.

4. Mubeen, S.; Lee, J.; Singh, N.; Kramer, S.; Stucky, G. D.; Moskovits, M. An autonomous photosynthetic device in which all charge carriers derive from surface plasmons. Nat. Nanotechnol. 2013, 8, 247.

5. Melvin, A. A.; Illath, K.; Das, T.; Raja, T.; Bhattacharyya, S.; Gopinath, C. S.; M-Au/TiO 2 $(\mathrm{M}=\mathrm{Ag}, \mathrm{Pd}$, and $\mathrm{Pt})$ nano photocatalyst for overall solar water splitting: role of interfaces. Nanoscale 2015, 7, 13477. 